\title{
ПРОФІЛАКТИКА ТА КОРЕКЦІЯ ПОРУШЕНЬ ПОСТАВИ РІЗНИМИ МЕТОДАМИ ФІЗИЧНОЇ РЕАБІЛІТАЦІї
}

\author{
Н. О. Давибіда, Т. Я. Кулик \\ Тернопільський національний медичний університет \\ імені І. Я. Горбачевського МОЗ України
}

Порушення постави займають одне з перших місць серед захворювань опорно-рухового апарату. Відомо, що між станом опорно-рухового апарату і здоров'ям людини існує дуже тісний зв'язок. Відсутність відхилень у стані опорно-рухового апарату $є$ обов'язковою умовою нормального функціонування органів і систем, підтримання доброго фізичного стану та працездатності. Незважаючи на значні успіхи, досягнуті протягом останнього десятиліття, в діагностиці та лікуванні цієї патології, проблема залишається актуальною.

\section{PREVENTION AND CORRECTION OF POSTURAL DISORDERS BY DIFFERENT METHODS OF PHYSICAL REHABILITATION}

\author{
N. O. Davybida, T. Ya. Kulyk
}

\section{Horbachevsky Ternopil National Medical University}

Violation of posture occupy one of the first places among the diseases of musculoskeletal system. It is known that there is a very close relationship between the state of musculoskeletal system and human health. The absence of deviations in the state of musculoskeletal system is a prerequisite for the normal functioning of organs and systems, maintaining a good physical condition and working capacity. Despite the significant successes achieved in the last decade in the diagnosis and treatment of this pathology, the problem remains relevant.

Вступ. Згідно з наявними статистичними даними, поширеність порушень постави серед школярів 1-3 класів складає 40-50\%.

Питання порушень постави серед дітей молодшого шкільного віку детально описані в працях вітчизняних і зарубіжних авторів. Проте ця проблема залишається актуальною і на сьогодні, викликаючи інтерес фахівців у галузі фізичної реабілітації.

Постава має нестійкий характер у період посиленого росту тіла дитини, що припадає на молодший шкільний вік. Це пов'язано з неодночасним розвитком кісткового, суглобово-зв'язкового апаратів і м'язової системи дитини. Кістки і м'язи збільшуються у довжині, а рефлекси статики ще не пристосувалися до цих змін $[3,5]$. Створення загальноосвітніх шкіл нового типу призводить до перевантажень дитячого організму через збільшення тривалості занять і об'єму

(c) Н. О. Давибіда, Т. Я. Кулик, 2020 навчального матеріалу [7, 9]. Сумарний об'єм знань, який отримують учні у сучасній українській школі, набагато перевершує їхні можливості його засвоєння, що призводить до погіршення стану здоров'я. Зокрема, це $\epsilon$ причиною виникнення відхилень від нормальної постави. Вже через рік після початку навчання у школі кількість дітей з порушеною поставою значно збільшується $[4,6]$.

Дефектна постава створює умови для прояву захворювань хребта й інших органів опорно-рухового апарату, що призводять до розладів діяльності внутрішніх органів. У дітей з порушеннями постави знижена життєва ємність легень, зменшена екскурсія грудної клітки і діафрагми, що несприятливо відображається на діяльності серцево-судинної та дихальної систем. Порушенню нормальної діяльності органів черевної порожнини сприяє слабкість м'язів живота. Зниження ресорної функції хребта у дітей з плоскою 
спиною спричиняє постійні мікротравми головного мозку під час ходьби, бігу й інших рухів, що негативно відображається на вищій нервовій діяльності, супроводжується швидким настанням втоми, а нерідко і головним болем [2].

У системі фізичного виховання школярів із порушеннями постави застосовують переважно один засіб корекції - фізичні вправи. Разом із тим, можна вважати, що масаж може ефективно доповнити дію фізичних вправ, оскільки він $є$ активним засобом оздоровлення організму людини. Позитивний вплив масажу відображається на лімфатичній системі та системі кровообігу, нервово-м'язовому і зв'язковому апаратах. У зв'язку з цим, доцільно розглядати масаж як процедуру, що створює оптимальні умови корекції постави школярів молодших класів у комплексі з фізичними вправами. Вказане поєднання в клінічних умовах виявилося дуже ефективним [8] і перенесення такого досвіду на практику роботи у лікувальній фізичній культурі з учнями загальноосвітніх шкіл $\epsilon$ вельми перспективним.

Школярі з порушеннями постави мають можливість усунення їх при повному застосуванні лікувальних заходів в умовах поліклініки, фізкультурного диспансеру і спеціальних шкіл-інтернатів [1]. Використання масажу в загальноосвітній школі дозволить охопити більшу кількість учнів з початковими стадіями відхилення від нормальної постави, оскільки до лікувальних установ звертаються діти вже зі значно вираженими порушеннями постави.

Мета роботи - розробити методику корекції порушень постави школярів молодших класів на основі поєднання фізичних вправ і масажу.

Основна частина. Враховуючи зміни, що відбуваються в процесі корекції порушеної постави, до яких належать зростаюча адаптація організму дитини до фізичного навантаження, а також перебудова змісту рухового режиму, ми поділяли весь процес на три етапи - вступний, основний і завершальний.

На вступному етапі вирішували завдання відновлення механізмів адаптації організму дитини до фізичного навантаження, захисних механізмів і систем, які в нормі підтримують необхідну рівновагу організму. Протягом цього етапу дітям пояснювали як правильно виконувати фізичні вправи, призначені для самостійних занять вдома. Основними засобами були загальнорозвиваючі гімнастичні вправи і вправи для формування навику правильної постави.
Виправлення наявного дефекту, покращення фізичного розвитку і фізичної підготовленості, прискорення процесу корекції постави були завданнями основного етапу. Для вирішення цих завдань використовували вправи для зміцнення м'язового корсета (загальнорозвиваючі вправи з предметами, вправи для формування і закріплення навику правильної постави, рухливі ігри), а також застосовували прийоми масажу відповідно до виду порушення постави.

Завершальний етап забезпечував перехід до наступного етапу виправлення порушеної постави, а також до звичайних умов фізичного виховання. У цей період вивчали комплекси фізичних вправ для самостійних занять вдома. До завдань завершального етапу входили закріплення навику правильної постави і вміння зберігати її при динамічній і статичній м'язових роботах. На цьому етапі застосовували вправи для загального тренування організму і вправи, спрямовані на виправлення порушеної постави дитини.

як було вищезазначено, заняття із виправлення порушень постави школярів молодших класів проходили під час спортивної години на групі продовженого дня. На заняттях виконували фізичні вправи і рухливі ігри для виправлення порушень постави, їх підбирали відповідно до вікових та індивідуальних особливостей дитини.

При організації занять враховували також фізіологічні особливості дій м'язових скорочень на організм дитини. У зв'язку з цим, кожне заняття, тривалістю 45 хв, включає вступну, основну і завершальну частини. Заняття проводили груповим способом.

Вступна частина заняття займала приблизно 11-17 \% часу всього заняття і включала прості за характером виконання вправи, такі, як ходьба та біг різними способами. Подібні вправи використовували з метою підготовки організму дитини до підвищеного рівня навантаження. У цю частину заняття так само входили власне гімнастичні вправи для формування і закріплення навику правильної постави і комплекси вправ ігрового характеру. Зоровий самоконтроль здійснювався перед дзеркалом, де діти приймали правильну поставу і виправляли зазначені порушення.

67-78 \% часу заняття відводять на основну частину. Тут використовували фізичні вправи для зміцнення м'язового корсета (загальнорозвиваючі гімнастичні вправи і рухливі ігри). У групу вправ для зміцнення м'язового корсета увійшли гімнастичні вправи для м'язів спини, черевного пресу і бічних м'язів тулуба. 
Ці вправи застосовували з метою відновлення і нарощування загальної та силової витривалості даних груп м'язів. Загальнорозвиваючі гімнастичні вправи забезпечували під час занять стимуляцію і нормалізацію м'язів пояса верхніх кінцівок, м'язів тазового пояса, м'язів черевного пресу. Для посилення ефективності цих вправ використовували палиці, обручі, м'ячі тощо, а також гімнастичні снаряди - стінки, лавки.

Завершальна частина заняття, що займала 9-16 \% часу, забезпечувала поступове зниження фізичного навантаження до рівня, близького до початкового рухового режиму, на якому перебували діти. Для цього використовували вправи, які сприяли прискоренню відновного процесу.

Головним анатомічним чинником при формуванні правильної постави є гармонійний розвиток мускулатури. При порушеній поставі вплив цього чинника послаблений внаслідок нерівномірного (посиленого або ослабленого) розвитку м'язів, трофіка яких погіршена. Тому при виправленні порушень постави стає абсолютно очевидною необхідність підвищення трофіки цих м'язів. Цей процес залежить від систематичної дії фізичних вправ на певні групи м'язів. Тим часом, фізичні вправи не можуть поліпшити живлення одного конкретного м'яза або окремо взятої групи м'язів. При виконанні фізичних вправ м'язовий апарат дитини перебуває у динамічному або статичному напруженні, тому впливу піддаються не тільки ті м'язи, на зміцнення яких спрямована ця вправа, але й інші групи м'язів. Процес покращення трофіки м'язів посилюється шляхом застосування масажу, оскільки здійснюється тактильна дія безпосередньо на ізольовані м'язи або на групу м'язів.

Завдання масажу при змінах фізіологічних вигинів хребта зводяться до підвищення загального тонусу організму; зміцнення м'язів спини, живота, грудей, шиї, нижніх кінцівок; формування правильної постави.

При проведенні масажу необхідно враховувати протипоказання до його застосування, від яких залежить ефективність масажу. Протипоказання до застосування масажу: гострі гарячкові стани; гострий запальний процес; кровотечі, кровоточивість; гнійні процеси будь-якої локалізації; захворювання шкіри інфекційної, грибкової етіології, шкірні висипання, ушкодження і подразнення шкіри, а також гострі шкірні алергічні реакції (кропив'янка та ін.); крово- виливи на шкірі; запалення лімфатичних вузлів і судин; захворювання вегетативної нервової системи в період вираженого запального процесу.

Уточнивши завдання масажу при змінах фізіологічних вигинів хребта, ми вважаємо правомірними перейти до обґрунтування методики масажу при різних видах порушень постави в сагітальній площині. У даній роботі пропонується методика масажу за трьома видами порушення постави, таких, як збільшений шийний лордоз, збільшений грудний кіфоз і збільшений поперековий лордоз. При кожному з названих видів порушень процедура масажу має свої характеристики і здійснюється по-різному. Той або інший вид порушення постави визначає характер виконання прийомів масажу, а також методичні вказівки щодо його застосування.

Висновки. При різних видах порушень постави в сагітальній площині ефективним вважають застосування лікувального класичного масажу, завданнями якого $є$ зміцнення м'язів спини, живота, шиї, нижніх кінцівок; підвищення загального тонусу організму.

При кожному виді порушень постави використовували прийоми масажу, різні за характером та їх виконанням. У свою чергу, характер виконання прийомів визначався трьома основними компонентами: силою тиску, темпом, тривалістю. У процесі корекції порушень постави молодших школярів широко використовують фізичні вправи і рухливі ігри. Ці форми фізичного розвитку включають в заняття з урахуванням вікових та індивідуальних особливостей дітей. Процес корекції порушеної постави передбачає три періоди - вступний, основний і завершальний. Тривалість кожного періоду склала, відповідно, 3 і 5 тижнів, протягом яких із школярами проводили спеціально підібрані вправи, спрямовані на виправлення наявного дефекту постави. Вправи відповідали віковим та індивідуальним особливостям дітей, узгоджували із завданнями періоду і проводили з урахуванням методичних рекомендацій. Подібні фізичні вправи були включені в кожне заняття. Такий підхід до організації процесу корекції порушень постави дозволив дати позитивну відповідь на питання про доцільність і ефективність використання фізичних вправ у поєднанні з масажем, в плановому фізичному вихованні молодших школярів. 


\section{СПИСОК ЛІТЕРАТУРИ}

1. Войчишин Л. Корекція і профілактика порушень постави у підлітків засобами фізичної реабілітації / Л. Войчишин // Молода спортивна наука України. 2009. - T. 3. - C. 35-39.

2. Грейда Н. Б. Корекція постави підлітків засобами фізичної реабілітації / Н. Б. Грейда, О. С. Грицай, В. У. Кренделєва // Слобожанський науково-спортивний вісник. - 2011. - № 4. - С. 119-123.

3. Коцур Н. І. Порушення постави в учнів середнього шкільного віку та їі корекція засобами фізичної реабілітації / Н. І. Коцур // Молодий вчений. - 2019. - № 4.1 (68.1). - C. 47-52.

4. Курса М. Фізична реабілітація дітей віком 11-12 років зі сколіозом II ступеня / М. Курса, О. Стасюк, С. Єфімова // Спортивна наука України. - 2014. - № 2 (60). - С. 10-14.
5. Мухін В. М. Фізична реабілітація : підручник / В. М. Мухін. - К. : Олімпійська література, 2000. - 559 с.

6. Пєшкова О. В. Комплексна фізична реабілітація при сколіотичній поставі / О. В. Пєшкова, О. М. Авраменко // Слобожанський науково-спортивний вісник. - 2009. № 2. - С. 84-88.

7. Соколова Н. Г. Практическое руководство по детской лечебной физкультуре / Н. Г. Соколова. - Ростов-на-Дону : Феникс, 2010. - 448 с.

8. Ставінська О. М. Засоби фізичної реабілітації при сколіозі у дітей / О. М. Ставінська // Реабілітаційні та фізкультурно-рекреаційні аспекти розвитку людини. 2017. - № 1. - С. 73-78.

9. Щирба В. А. Причини, профілактика та корекція порушень постави / В. А. Щирба // Теорія та методика фізичного виховання. - 2016. - № 03. - С. 28-34.

Отримано 23.01.20 